\title{
Comparison of Prevalence of Hypertension and Medical Expenses According to the Level of Physical Activity of Korean Adults
}

\section{Byung Kun Lee ${ }^{1 *}$}

'Sangmyung University, Cheonan, Korea

\author{
Received: September 4, 2018 \\ Accepted: October 23, 2018 \\ Published online: October 31, 2018 \\ Keywords: \\ Korean adults \\ Medical expenses \\ Physical activity \\ Prevalence of hypertension
}

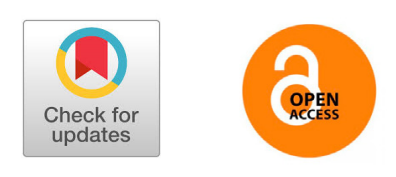

\begin{abstract}
OBJECTIVES The purpose of this study is to compare the differences in the prevalence of hypertension in relation to the physical activity grade and to analyze differences in the days of hospitalization of hypertension patients, drug expenses and personal medical expenses.

METHODS The Korea medical panel data was used in 2016, with a total of 13,276 adults and 3,470 hypertension patients. Physical activity was measured with IPAQ and converted to MET-minutes per week. The days of hospitalization, monthly average for hypertension drug expenses, and personal medical expenses were investigated, and frequency analysis, logistic regression, and ANOVA were performed.

RESULTS The prevalence of hypertension based on the inactive group were decreased both minimally active group (odds ratio $[O R]=0.89$ ) and the active group $(O R=0.77, p<0.01)$. The days of hospitalization, drug expenses, and personal medical expenses for hypertension were all significantly different among each physical activities group ( $p<.01$ ). Days of Hospitalization and medical expenses have increased by 4.1 to $28.6 \%$ in minimally active group compared with active group, while inactive groups have increased by 23.6 to $65.7 \%$, increasing more rapidly in inactive groups.

CONCLUSIONS The prevalence of hypertension was further reduced in the order of minimally active and activity groups compared to inactive groups, and it makes lower the medical use and medical expenses associated with the level of physical activity of hypertension patients.
\end{abstract}

( The Asian Society of Kinesiology and the Korean Academy of Kinesiology

\section{서론}

세계보건기구(WHO)는 신체활동 부족은 전 세계 10 대 사망원인 요인 중 하나이며, 심혈관계질환, 암, 당뇨병과 같은 비감염성질환의 주요 위험요인이고, 세계적으로 성 인 4 명중 1 명만이 충분한 신체활동을 실천하고 있으며, 전 세계 청소년의 $80 \%$ 이상이 권장하는 신체활동량을 실천

*Correspondence: Byung Kun Lee, Department of Lifetime Sports and Leisure, Sangmyung Univeristy, 31 Sangmyungdae-gil, dongnam-gu, Cheonan, ChungNam, Republic of Korea.

E-mail: bklee@smu.ac.kr
하지 못하고 있다고 제시하고 있다고 하였다[1]. 한국의료 패널에서도 고혈압, 당뇨병, 고지혈증, 관절병증, 결핵, 허 혈성 심장질환, 뇌혈관 질환을 7대 만성질환을 중심으로 조사해 오고 있다.

고혈압은 순환계 심혈관질환 중 전 세계적으로 유병률 이 가장 높고 심혈관질환의 발병에 중요한 위험요인으로 알려졌으나, 운동과 식이요법 등으로 충분히 조절이 가능 하다고 보고되고 있다[2]. 규칙적인 신체활동은 고혈압, 당뇨병, 심장질환 사망 위험률, 직장암 등의 감소, 체중조 절, 건강한 뼈와 관절 유지, 심리학적 안녕 유지 등에 긍 정적인 효과가 있다고 보고되고 있다[3,4]. 운동은 고혈 
압과 같은 순환계 심혈 관질환을 호전시키는데 도움이 된 다고 보고되었으며[4], 다양한 양식으로 진행되어 왔다.

Cornelissen et al. [5]은 조깅과 사이클과 같은 규칙적인 유 산소 운동이 안정시 혈압을 $3.5 / 2.5 \mathrm{mmHg}$ 정도 저하시키 는 작용을 한다고 하였다. Carlson et al. [6]은 운동 양식을 달리하여 4 주 이상의 등척성 저항운동을 통해 안정시 혈 압을 약 $6.77 / 3.94 \mathrm{mmHg}$ 저하시킨다고 하였다. Lee [7]은 2015년 국민건강영양조사 자료를 이용하여 악력이 높을 수록 고강도 운동, 근력운동, 유연성 운동에 더 많이 참여 하고 있었으며, 악력이 높을수록 고혈압의 유병률이 낮게 나타났다고 하였다.

신체활동과 비만 및 의료이용의 관계를 분석한 연구를 살펴보면, 신체활동 정도가 입원빈도와 입원기간과 유의 한 상관관계가 보고되고 있으며[8], 신체활동을 하지 않 는 사람이 적극적인 신체활동을 하는 사람보다 입 원진료 이용률이 약 $38 \%$ 더 높았다고 보고되고 있다[9]. 비만군 이 정상군에 비해 외래 이용확률이 유의하게 높고 진료 비 지출도 유의하게 더 많이 하는 것으로 나타났으나 입 원 이용에는 비만이 통계적으로 유의한 영향을 미치지는 않았다[10].

하지만 한국인을 대상으로 대표성 있는 최신 자료를 활용하여 어느 정도의 신체활동 수준이 고혈압 유병률을 개선시키는 지에 대한 연구는 적은 수로 진행되었다. 의 료이용과 의료비용 조사 내용이 상대적으로 부족한 국민 건강영양조사 자료를 이용하였거나 특정 연령을 이용해 연구한 것이었다. 고혈압 질환자의 의료이용과 의료비용 등에 어떠한 차이가 있는지에 대해 종합적으로 분석한 연 구는 미미한 실정이었다.

본 연구의 목적은 최신 자료인 2016년 한국의료패널의 성인을 대상으로 하여 신체활동 등급에 따른 고혈압 유병 률의 차이를 비교하고, 신체활동 등급에 따른 고혈압 환 자의 연간 입원일수, 월평균약값 및 연간 의료비용 등의 차이를 분석하는데 있다.

\section{연구 방법}

\section{분석자료 및 연구대상}

본 연구는 한국인을 모집단으로 조사한 자료인 제 11 차 2016 한국의료패널 원시자료를 이용하였다. 한국의료 패널은 정부승인 지정통계조사(승인번호 92012호, 2007 년)이며, 2008년부터 매년 보건의료이용실태와 의료비
지출수준, 건강수준 및 건강행태 등에 관한 기초자료를 매년 조사하고 있는 패널조사로 최근 자료는 2016년이었 으며 본 연구의 대상 자료이다. 전국규모의 대표성을 유 지하기 위해 2005년 인구주택총조사 자료를 추출틀로 하 고 있다. 표본은 1 단계에서 표본조사구(집락) 추출하고, 2 단계에서 표본가구를 추출하는 2 단계 확률비례 층화집 락추출 방법으로 선정하였다. 조사구 수는 약 350 개로서 2008년 원표본 7,866가구를 대상으로 진행하였으며, 2013 년에 신규표본 2,222 (6,454가구원)을 추가 추출하여 조사 를 수행하고 있다. 본 연구의 대상은 2016년 자료 중 성인 20 세 이상의 남녀 총 13,276 명이었고, 이 중 의사에 게서 고 혈압으로 진단받은 환자는 3,470 명이었다. 대상 자료는 응답자에 부여된 가구와 가구원 ID를 기준으로 통합하여 연간데이터를 생성하였다. 연구 대상자 특성인 인구실 태, 체격자료 및 건강과 질병의 자료는 <Table 1>과 같다.

\section{변수의 정의 및 측정도구}

신체활동은 IPAQ(International Physical Activity Questionnaire)[11]의 단문형을 이용하여 측정하였다. 단문형 은 7 개의 문항으로 국가 혹은 지역관리 시스템에 적합 한 형태이며, 장문형은 27 개의 문항으로 심도 있는 자료 수집에 적합한 형태이다. IPAQ 단문형은 최근 7일 동안 10 분 이상 실시한 격렬한 신체활동, 중등도 활동 및 걷 기의 주당 일수, 평균 시간(일당 시간, 분)에 대한 설문 으로 구성되어 있다. 신체활동량은 설문 자료를 토대로 주당 MET(metabolic equivalent)-분으로 환산하여 이용하 였다. 걷기는 $3.3 \mathrm{MET}$, 중등도 활동은 $4.0 \mathrm{MET}$, 격렬한 활 동은 $8.0 \mathrm{MET}$ 로 설정하였다. 고활동(active) 집단은 주당 $3,000 \mathrm{MET}$-분 이상이며, 최소활동(minimally active) 집단 은 600 3,000MET-분, 비활동(inactive) 집 단은 $600 \mathrm{MET}$-분 미만으로 분류하였다[11].

연간 입원일수는 1 년 동안 병원에 입원한 일수의 총 합 이다. 월평균약값은 고혈압 질환을 관리 및 치료하기 위 해 지불하는 매월 평균의 약값이다. 연간 개인의료비 I은 응급, 입원과 외래의료비 및 처방약값을 수납금액을 기 준으로 합한 것이며, 연간 개인의료비 ॥는 연간 개인의료 비 에 응급, 입원과 외래교통비와 입원간병비를 합한 것 이다. 의료비 관련 금액은 원(Won) 단위로 조사하였으며, 달러(\$)로 표시할 때는 $\$ 1$ 를 $W 1,100$ 으로 환산하여 표시하 였다. 
Table 1. Characteristics of the study population $(\mathrm{N}=13,276)$

\begin{tabular}{|c|c|c|c|c|}
\hline Variables & Categories & $\mathrm{N}$ & $\%$ & Mean \pm SD \\
\hline \multicolumn{5}{|l|}{ Demographics } \\
\hline \multirow{2}{*}{ Sex } & Male & 6,098 & 45.9 & \\
\hline & Female & 7,178 & 54.1 & \\
\hline Age & & & & $53.5 \pm 17.3$ \\
\hline \multicolumn{5}{|c|}{ Physical measurements } \\
\hline Height(cm) & & & & $163.5 \pm 9.0$ \\
\hline Weight(kg) & & & & $62.5 \pm 11.4$ \\
\hline Body mass index & & & & $23.3 \pm 3.1$ \\
\hline \multicolumn{5}{|c|}{ Health habit and disease } \\
\hline \multirow{2}{*}{ Smoking } & Smoker & 4,999 & 37.7 & \\
\hline & Nonsmoker & 8,277 & 62.3 & \\
\hline \multirow{4}{*}{ Drinking } & Nondrinker & 3,495 & 26.3 & \\
\hline & Below 1 time per month & 3,031 & 22.8 & \\
\hline & 1 to 3 times per month & 3,000 & 22.6 & \\
\hline & Above 1 time per week & 3,750 & 28.2 & \\
\hline \multirow{2}{*}{ Disease } & Hypertension & 3,470 & 26.1 & \\
\hline & Non-hypertension & 9,806 & 73.9 & \\
\hline
\end{tabular}

\section{자료처리방법}

자료분석은 IBM SPSS Statistics 23.0을 사용하였고, 자료 는 가구원 일반사항, 고혈압 진단 여부 판정, 신체활동 산 출 및 등급 판정, 연간 입원일수, 월평균약값, 연간 개인 의료비를 대상으로 하여 분석하였다. 연구대상자의 성별 과 건강습관 및 질병 등 요인에 대하여 빈도분석을 실시 하였으며, 연령과 체격요인을 대상으로 기술분석을 실시 하였다. 신체활동 집단에 따른 고혈압 유병률의 차이를 알아보고, BMI(body mass index), 흡연과 음주 변수를 공 변량으로 통제하고 고혈압 유병률 차이를 비교하기 위하 여 로지스틱 회귀분석(logistic regression analysis)을 실시 하였다. BMI는 원수치로 분석하였고, 흡연은 흡연과 비 흡연으로 구분하였고, 음주는 평생금주, 최근 1 년간 금주, 월 1 회 미만, 월 1 회, 월2 3회, 주 1 회, 주 2 3회, 거의 매일 로 구분하여 분석하였다. 고혈압 환자의 신체활동 집단에 따른 월평균약값과 연간 개인의료비를 비교하기 위하여 변량분석(analysis of variance: ANOVA)을 실시하였다. 고 혈압 환자를 대상으로 하여 신체활동 집단에 따른 주당 총 MET-분, 월평균약값 및 개인의료비를 비교하기 위하 여 변량분석을 실시하고 Duncan 방법으로 사후검증을 실 시하였다. 통계적 유의수준 $\alpha=.05$ 로 하였다.
결과

<Table 2>는 신체활동 집단에 따른 고혈압 유병률의 차 이를 알아보기 위하여 로지스틱 회귀분석을 실시한 결 과이다. 비활동 집단의 고혈압 유병률을 1.00 으로 하였 을 경우 최소활동 집단의 유병률의 OR이 $0.89(95 \% \mathrm{CI}=$ 0.76-1.04)로 $11.5 \%$ 였고, 고활동 집단의 유병률의 $\mathrm{OR}$ 이 $0.77(95 \% \mathrm{CI}=0.66-0.90)$ 로 $23.3 \%(\mathrm{p}<.01)$ 감소하는 것으 로 나타났다. 고혈압 유병률을 BMI, 흡연과 음주 변수를 공변량으로 통제하고 분석한 결과, 최소활동 집단의 $\mathrm{OR}$ 은 $0.90(95 \% \mathrm{CI}=0.76-1.06)$ 으로 $10.1 \%$ 였고 $(\mathrm{p}=0.202)$, 고 활동 집단의 유병률의 $\mathrm{OR}$ 이 $0.81(95 \% \mathrm{CI}=0.69-0.90)$ 로 $19.4 \%(\mathrm{p}<.01)$ 감소하는 것으로 나타났다. 즉, 신체활동 집 단이 상승할수록 고혈압 유병률이 $11.5 \%$ 에서 $23.3 \%$ 감소 하며, 공변량을 통제한 경우에는 $10.1 \%$ 에서 $19.4 \%$ 감소하 는 것으로 나타났다.

<Table 3>은 고혈압 환자의 신체활동 집단에 따른 연간 입원일수, 고혈압 월평균약값과 연간 개인의료비를 비교 하기 위하여 변량분석을 실시한 결과이다. 연간 입원일 수, 고혈압 환자의 월평균약값, 연간 개인의료비 | 및 연 간 연간 개인의료비 $\|$ 는 모두 신체활동 집단간에 유의한 차이가 나타났다 $(\mathrm{p}<.01)$. 연간 입 원일수는 고활동 집단이 $7.0 \pm 6.6$ 일이었으며, 최소활동 집단은 $9.0 \pm 12.8$ 일로 $28.6 \%$, 
Table 2. Hypertension prevalence according to physical activity grade

\begin{tabular}{lccccc}
\hline Physical activity grade & $\mathrm{N}(\%)$ & $\begin{array}{c}\text { Unadjusted OR } \\
(95 \% \mathrm{Cl})\end{array}$ & $\mathbf{p}$ & $\begin{array}{c}\text { Hypertension } \\
\text { Adjusted OR } \\
(95 \% \mathrm{Cl})\end{array}$ & $\begin{array}{c}1.00 \\
\mathbf{p}\end{array}$ \\
\hline $1^{\text {st }}$ grade inactive & $6801(51.2)$ & 1.00 & & $0.90(0.76 \sim 1.06)$ & 0.202 \\
$2^{\text {nd }}$ grade minimally active & $5461(41.1)$ & $0.89(0.76 \sim 1.04)$ & 0.135 & $0.81(0.69 \sim 0.95)$ & $0.009 * *$ \\
$3^{\text {rd }}$ grade active & $1014(7.6)$ & $0.77(0.66 \sim 0.90)$ & $0.001 * *$ & & \\
\hline OR: Odds ratio, 95\% Cl: 95\% Confidence Interval. & & & & &
\end{tabular}

Table 3. Days of hospitalization, drug expenses for hypertension, and personal medical expenses according to physical activity grade of hypertension patients

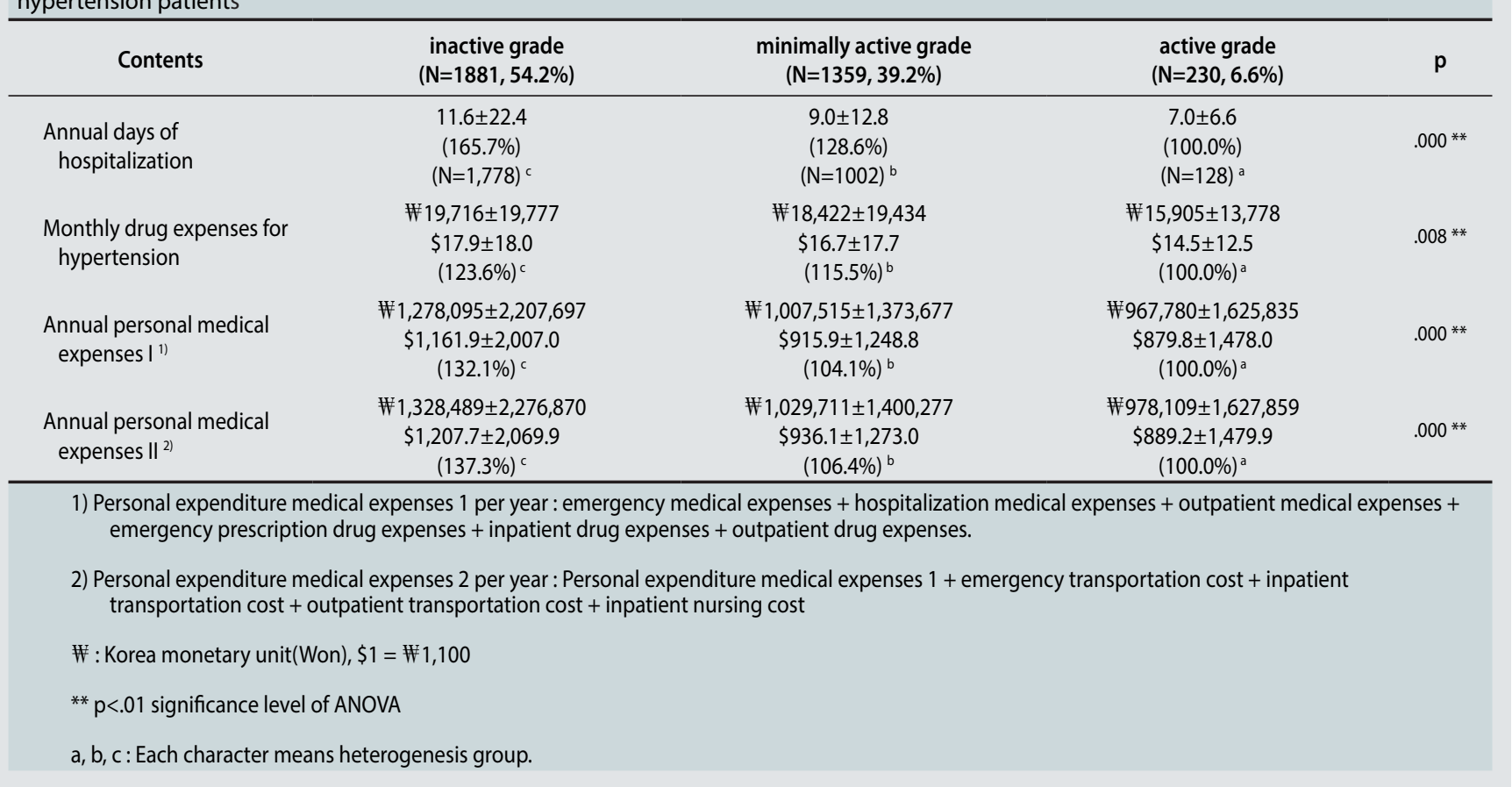

비활동 집단은 $11.6 \pm 22.4$ 일로 $65.7 \%$ 급격히 증가하였고 3 집단 모두 유의한 차이가 나타났다 $(\mathrm{p}<.01)$. 월평균약값

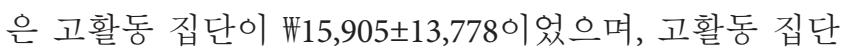
에 비해 최소활동 집단은 $15.5 \%$ 증가하여 $W 18,422 \pm 19,434$ 이며, 비활동 집단은 $23.6 \%$ 증가하여 $\# 19,716 \pm 19,777$ 으 로 나타났다. 연간 개인의료비 I은 응급, 입원과 외래의 료비 및 처방약값을 합한 것이며, 연간 개인의료비 는 연간 개인의료비 |에 응급, 입원과 외래교통비와 입원간 병비를 합한 것이다. 연간 개인의료비 은 고활동 집단

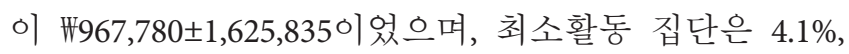
비활동 집단은 $32.1 \%$ 증가하였고 3 집단 모두 유의한 차 이가 나타났다. 연간 개인의료비 는 고활동 집단이

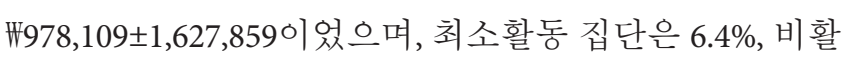

동 집 단은 $37.3 \%$ 증가하였고 3 집 단 모두 유의한 차이가 나 타났다. 고활동 집단을 기준으로 입원일수와 의료비를 비 교해 보면 비활동 집단은 4.1 28.6\% 증가하였으나 비활동 집단은 23.6 65.7\% 증가하여 비활동 집단에서 더 급격하 게 증가하는 것으로 나타났다.

\section{논의}

패널데이터는 일반 횡단면 자료에서 시계열 형태 자료 가 추가되어 자료 구조가 복잡하며, 일반 다중회귀분석 이외에 일반화 추정 방정식(Generalized Estimating Equations)을 적용할 수 있다. 시계열 자료와 횡단면 자료를 병 합한 것은 유사하나, 국민건강영양조사와 같은 합동 횡단 
면 자료와 달리 동일한 개체를 반복적으로 관찰하여 조사 하는 자료이다. 본 연구에서는 한국의료패널 자료를 이용 하여 신체활동 수준에 따른 고혈압 유병률, 의료이용 및 의료비 등의 차이를 분석하였다.

신체활동 설문지는 단시간에 대상자의 신체활동 측정 이 가능하므로 대규모의 역학 연구에서 많이 사용된다. 본 연구에서 사용한 IPAQ는 대규모 역학연구, 국민건강 영양조사와 의료패널 등의 조사에서 사용하고 있다. 그 러나 주 단위의 신체활동량을 평가하는데 있어서 유용하 지만 대상이 최근 7일로 제한되어 있으므로 신체활동 패 턴이 평상시와 다를 경우, 한 번의 설문조사만으로는 일 상 신체활동량 혹은 에너지 소비량을 평가하기 어렵다는 단점이 있다[12].

신체활동에 참여하는 것은 만성질환 위험인자를 감소 시킬 뿐 아니라 전체 사망 위험률을 감소시킨다고 보고되 고 있다[3]. 규칙적인 신체활동은 고혈압[13], 당뇨병[14, 15] 및 관상동맥 심장질환[16] 등의 질환 위험인자의 개선 에 유의한 상관이 있다고 보고되고 있다. Laaksonen et al. [17]은 남성의 경우 $4.5 \mathrm{METs}$ 이상 주당 3 시간 이상 운동집 단이 주당 1 시간 이하 집단보다 대사증후군의 위험률이 $48 \%$ 낮게 나타났으며, 60 분 이상의 고강도 운동을 한 사 람은 대사증후군의 위험률이 3 분의 2 가 낮게 나타난다고 하였다. 본 연구에서도 저활동 집단이 비해 중활동 집단 의 고혈압 유병률의 $\mathrm{OR}$ 이 $0.89(11 \%)$, 고활동 집단의 유병 률의 OR이 $0.77(23 \%)$ 로 감소하여 신체활동이 고혈압 개 선에 도움이 된다는 것을 지지하였다<Table 2>.

근력 요소 중에서 악력도 건강 질환 관련 주요 지표라 는 연구도 다수 보고되어왔다. 한국 성인에게서 우측 최 저악력집단이 비해 3rd Quartile 집단의 고혈압 유병률 OR 이 0.93, 4th Quartile은 0.77로 나타났으며, 악력이 높을수 록 고혈압 유병률이 낮게 나타났다[7]. 브라질 성인 대상 으로 만성질환에 대해 조사한 결과 악력이 높은 그룹과 비교하여 낮은 그룹에서 고혈압 $\mathrm{OR}$ 이 2.21 , 당뇨는 4.18 , 합병증은 1.99 로 나타나 유병률이 높게 나타났다[18]. 스 웨덴의 군인을 대상으로 37년간 추적 조사한 결과 악력 은 심혈관질환과 뇌졸중과 역상관관계가 보고되었으며 [19], 노인에서도 악력은 노인의 인지, 정서적 감정, 신체 기능, 사망률과도 관련이 나타났다[20,21]. 향후에는 악력 을 포함한 다양한 근력 운동이 만성 질환 개선에 미치는 영향을 더 분석할 필요가 있겠다.

신체활동과 근력운동이 질환에 미치는 영향은 신체
구성, 지질성분, 항산화작용, 세포자멸 등이 기여하는 것으로 보고되고 있다. 12 주간 복합운동 처치가 비만 여 대생에게 신체구성에 긍정적인 영향을 미쳤으며, 혈중 지질성분과 $\mathrm{CRP}$ (c-reactive protein) 농도를 감소시켜 비 만을 포함한 대사성질환의 위험률까지도 감소시켰고, $\mathrm{MDA}$ (malondialdehyde) 및 GPX(Glutathione peroxidase)의 농도 변화는 항산화방어 기전을 증가시켜 항산화 체계에 도 효율적으로 작용한 것이라고 하였다[22]. 규칙적인 운 동은 혈압을 낮추고 미토콘트리아의 기능을 향상시키고, 염증지표, 산화적 스트레스, 골격근에서의 세포자멸을 줄이는 데 기여하는 것으로 보고되었다[23, 24]. 이러한 운 동의 순기능을 통해 고혈압과 같은 질병의 유병률을 낮추 도록 기여한다고 할 수 있겠다.

Sari [9]는 Canadian Community Health Survey를 이용하 여 비활동인 경우 입원의료 이용 횟수가 $38 \%$ 증가하며, 주치의를 $5.5 \%$ 더 방문하고, 특별 서비스를 $13 \%$ 더 이용 한다고 하였다. 한국의 경우 신체활동을 활발히 하면 노 인의 외래 이용 횟수가 감소하며, 주당 1 회 이상의 규칙적 으로 운동을 하면 비운동에 비하여 의료이용을 할 정도의 건강문제가 감소한다고 보고되고 있다[25].

한국 노인의 신체활동 정도와 의료이용과의 관련성에 대한 연구에서 비활동 집단과 활동 집단을 비교하면 입 원이용 가능성이 0.54 배, 약국이용은 0.75 배로 낮았으며, 의료이용횟수도 감소하는 것으로 나타났고, 최소활동 집 단을 비활동 집단과 비활동을 비교하여 입원의료이용 가 능성이 0.64 배로 낮고, 이용횟수도 감소하였다고 하였다 [25]. 중년 여성의 신체활동 강도에 따른 외래 의료이용차 이 분석에서 중증도 신체활동 빈도와 월평균 외래 의료 이용 횟수의 관계를 제외하면 모든 신체활동이 의료비와 의료 이용을 낮춘다고 보고되고 있다[26]. 본 연구의 < Table $3>$ 에서도 신체활동 수준이 감소할수록 연간 입원일수 가 고활동 등급의 $7.0 \pm 6.6$ 일에서 중활동과 비활동 등급은 $9.0 \pm 12.8$ 일과 $11.6 \pm 22.4$ 일로 $128.6 \sim 165.7 \%$ 가 증가하여 신 체활동이 의료이용 빈도 감소시키는 데 기여를 한다는 사 실을 지지하고 있다.

Koh [27]는 인슐린 비의존 당뇨병, 협심증, 급성심근경 색증, 결장암, 직장암, 유방암의 순으로 총 205,211,206천 원의 의료비가 신체활동 부족에 기인한 것으로 추정되고, 개략적 적용에 의한 의료비 추산시 당뇨병, 허혈성심질 환, 대장암, 유방암의 의료비 부담이 큰 것으로 나타나 이 에 대한 지속적 모니터링 및 보완연구가 필요하다고 하 
였다. 본 연구에서 활동 집단의 의료비를 살펴보면 고혈 압 월평균약값이 $W 15,905 \pm 13,778$ 이고, 연간 개인의료비 । 이 $\mathbb{W} 967,780 \pm 1,625,835$, 교통비 등이 포함된 연간 개인의료

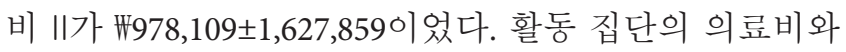
비교해 보면, 최소활동 집단의 의료비가 $4.1 \sim 15.5 \%$ 정도 많이 들었고, 비활동 집단은 23.6 37.3\% 정도 많이 소요되 었다. 즉, 비활동 집단에서 더 급격하게 의료비가 증가하 는 것으로 나타났다<Table 3>. 본 연구 결과는 신체활동이 의료비를 감소시키는 요인으로 작용하였다는 결과와 유 사하였다. 본 연구의 의료비는 대상자가지불한 수납금액 중심으로 조사되었으나 건강보험과 민간보험 등을 비율 과 이들을 포함하는 총의료비 차원에서도 접근할 필요가 있겠다. 이상의 연구들을 통해 신체활동 참여와 운동량을 증가시켜 건강 증진뿐만 아니라 의료이용 가능성을 낮추 어 사회적 비용을 줄일 수 있다고 할 수 있겠다.

본 연구에서 고혈압 환자 중에서 비활동 집단이 $54.2 \%$ 이고, 최소활동 집단이 $39.2 \%$, 활동집단이 $6.6 \%$ 로 나타났 으므로 비활동 집단의 비율을 $10 \sim 20 \%$ 정도 최소활동 집 단으로 개선시키려는 노력이 입원일수, 월약값 및 연간 의료비 감소 등을 통해 의료이용과 의료비 감소와 건강의 질 개선 등에 중요한 작용을 하리라 기대된다.

\section{결론}

고혈압 유병률은 비활동 집단에 비해 최소활동 집단 의 $\mathrm{OR}$ 이 0.89 , 고활동 집단이 $0.77(\mathrm{p}<.01)$ 로 감소하였고, $\mathrm{BMI}$, 흡연과 음주 변수를 통제하고 최소활동 집단의 $\mathrm{OR}$ 이 0.90 , 고활동 집단의 $\mathrm{OR}$ 이 $0.81(\mathrm{p}<.01)$ 감소하는 것으로 나타났다. 고혈압 환자의 신체활동 집단에 따른 연간 입 원일수, 고혈압 환자의 월평균약값, 연간 개인의료비는 모두 신체활동 집단간에 유의한 차이가 나타났다 $(\mathrm{p}<.01)$. 고활동 집단을 기준으로 입 원일수와 의료비를 비교해 보 면 최소활동 집단은 4.1 28.6\% 증가하였으나 비활동 집단 은 23.6 65.7\% 증가하여 비활동 집단에서 더 급격하게 증 가하는 것으로 나타났다. 고혈압 유병률은 비활동 집단에 비해 최소활동 집단과 고활동 집단 순으로 더 감소하였고 고혈압 환자의 신체활동 집 단에 따른 의료이용과 의료비 용이 신체활동이 감소할수록 더 증가하였다. 향후에는 신 체활동 이외에 정신건강과 삶의 질을 포함한 다양한 요소 가 의료이용과 의료비에 미치는 영향을 종단적으로 분석 할 필요가 있겠다.

\section{Acknowledgements}

본 논문은 2017년 상명 대학교 교내선발과제 연구비의 지원 을 받아 연구되었음

\section{Conflicts of Interest}

The authors declare no conflict of interest.

\section{References}

1. WHO : Physical activity Key facts [Internet]. [cited 03 September 2018]. Available from: http://www.who.int/ en/news-room/fact-sheets/detail/physical-activity.

2. Picon RV, Fuchs FD, Moreira LB, Riegel G, Fuchs SC. Trends in prevalence of hypertension in Brazil: a systematic review with meta-analysis. PLOS one. 2012; 7(10):e48255.

3. American College of Sports Medicine. ACSM's resource manual for guidelines for exercise testing and prescription. Wolters Kluwer: Lippincott Williams \& Wilkins; 2012, p 2-15.

4. Moraes MR, Bacurau RF, Casarini DE, Jara ZP, Ronchi FA, Almeida SS, et al. Chronic conventional resistance exercise reduces blood pressure in stage 1 hypertensive men. J Strength Cond Res. 2012; 26(4):1122-9.

5. Cornelissen VA, Smart NA. Exercise training for blood pressure: a systematic review and meta-analysis. J Am Heart Association. 2013; 2(1):e004473.

6. Carlson DJ, Dieberg G, Hess NC, Millar PJ, Smart NA. Isometric exercise training for blood pressure management: a systematic review and meta-analysis. Mayo Clinic Proceedings, Elsevier. 2014; 327-44.

7. Lee JA. Relationship between Grip Strength and Prevalence of Hypertension in Korean Adults: the Sixth Korea National Health and Nutrition Examination Survey (2015). J Kinesiology. 2017; 19(3):53-60.

8. Woolcott JC, Ashe MC, Miller WC, Shi P, Marra CA, PACC Research Team. Does physical activity reduce seniors' need for healthcare?: a study of 24281 Canadians. $\mathrm{Br}$ J Sports Med. 2010; 44(12):902-4. 
9. Sari N. Physical inactivity and its impact on healthcare utilization. Health Econ. 2009; 18(8):885-901.

10. Yoon NH, Kwon SM. Impact of obesity on health care utilization and expenditure. Kor J Health Econo Pol. 2013; 19(2):61-80.

11. Craig CL, Marshall AL, Sjostrom M, Bauman AE, Booth ML, Ainsworth BE, et al. International physical activity questionnaire: 12-country reliability and validity. Med Sci Sports Exerc. 2003; 35(8):1381-95.

12. Yang YJ, Yoon YS, Lee ES, Shin SH, Oh SW, Kim DH, et al. Development of self-administered questionnaire for the assessment of physical acitivity. Kor J Health Prom. 2005; 5(3):178-98.

13. Palatini P, Puato M, Rattazzi M, Pauletto P. Effect of regular physical activity on carotid intima-media thickness. Results from a 6-year prospective study in the early stage of hypertension. Blood Press. 2011; 20(1):37-44.

14. Plotnikoff RC, Lippke S, Courneya K, Birkett N, Sigal R. Physical activity and diabetes: An application of the theory of planned behaviour to explain physical activity for Type 1 and Type 2 diabetes in an adult population sample. Psychology and Health. 2010; 25(1):7-23.

15. Plotnikoff RC, Lippke S, Trinh L, Courneya KS, Birkett N, Sigal RJ. Protection motivation theory and the prediction of physical activity among adults with type 1 or type 2 diabetes in a large population sample. British journal of health psychology. 2010; 15(3):643-61.

16. Verdaet D, Dendale P, De Bacquer D, Delanghe J, Block P, De Backer G. Association between leisure time physical activity and markers of chronic inflammation related to coronary heart disease. Atherosclerosis. 2004; 176(2):303-10.

17. Laaksonen DE, Lakka HM, Salonen JT, Niskanen LK, Rauramaa R, Lakka TA. Low levels of leisure-time physical activity and cardiorespiratory fitness predict development of the metabolic syndrome. Diabetes Care. 2002; 25(9):1612-8.

18. Amaral Cde A, Portela MC, Muniz PT, Farias Edos S, Araujo TS, Souza OF. Association of handgrip strength with self-reported diseases in adults in Rio
Branco, Acre State, Brazil: a population-based study. Cad Saude Publica. 2015; 31(6):1313-25.

19. Silventoinen K, Magnusson PK, Tynelius P, Batty GD, Rasmussen F. Association of body size and muscle strength with incidence of coronary heart disease and cerebrovascular diseases: a population-based cohort study of one million Swedish men. Int J Epidemiol. 2008; 38(1):110-8.

20. Stessman J, Rottenberg Y, Fischer M, Hammerman-Rozenberg A, Jacobs JM. Handgrip Strength in Old and Very Old Adults: Mood, Cognition, Function, and Mortality. J Am Geriatr Soc. 2017; 65(3):526-32.

21. Oksuzyan A, Maier H, McGue M, Vaupel JW, Christensen $\mathrm{K}$. Sex differences in the level and rate of change of physical function and grip strength in the Danish 1905-cohort study. J Aging Health. 2010; 22(5):589610.

22. Mok DH. The effect of 12 weeks combined exercise training on inflammatory markers and antioxidant system in obese female college students [dissertation]. Seoul: Yonsei University Thesis; 2009.

23. Lackland DT, Voeks JH. Metabolic syndrome and hypertension: regular exercise as part of lifestyle management. Curr Hypertens Rep. 2014; 16(11):492,0140492-2.

24. Brook RD, Appel LJ, Rubenfire M, Ogedegbe G, Bisognano JD, Elliott WJ, et al. Beyond medications and diet: alternative approaches to lowering blood pressure: a scientific statement from the american heart association. Hypertens. 2013; 61(6):1360-83.

25. Kwak Kl, Baek CH, Ryu SY. Relationship between the physical activity levels and health care utilization in korean elderly. J Kor Acad Indust Cooper Soc. 2015; 16(1):617-26.

26. Cho YS. Differences in outpatients healthcare utilization by level of physical activity among middle-aged Korean women [dissertation]. Seoul National University Thesis; 2015.

27. Koh KW. Medical cost of physical inactivity. J Kinesiol. 2006; 8(2):57-62. 